\title{
MEASUREMENT OF BANKS' ECONOMIC EFFICIENCY UNDER CONDITIONS OF IMPERFECT COMPETITION
}

\author{
Jacek Barburski* \\ Faculty of Management, Cracow University of Economics, Cracow, Poland
}

\begin{abstract}
One of the modes of the measurement of banks' and their branches' economic efficiency is constituted by an econometric approach based on stochastic frontier functions. In this approach, the following three basic goal functions can be considered: the cost, revenue and profit functions. This paper aims to present alternative (relative to the standard formula) concepts of the measurement of revenue and profit efficiency constituting an important assessment criterion of banks' operations. The paper also presents the results of the empirical studies of revenue and profit efficiency, as exemplified by the selected commercial bank. The theoretical part of the paper proceeds from an introduction to present the premises of an alternative efficiency assessment, then the formulas of the frontier functions of revenue and a profit. These are formulas that can exclusively be used under the conditions of imperfect competition between banks. The empirical part focuses on the application of the above models to assess the efficiency of a Polish bank's branches. The calculations returned the indicators of revenue and profit efficiency and the rankings of the studied sample of branches in three different quarters. Due to the use of an excessively simple assessment method (Corrected Least Squares Method), the efficiency indicators obtained are understated and not accurate enough to lend themselves to further analysis. On the other hand, the rankings prepared on its basis are reliable and can be used for further assessments and comparisons, which should be considered as a meaningful research benefit.
\end{abstract}

Keywords: measurement of bank' efficiency, economic efficiency, alternative revenue efficiency, alternative profit efficiency, stochastic frontier models

JEL Classification: C01, C61, D24, G21

\section{INTRODUCTION}

In a bid to maximise profit, each and every financial institution should, on the one hand, strive to maximise its revenue, and on the other, to rationally use factors of production. Stiff competition, though, makes the maximisation of sales revenue ever more difficult.

* Correspondence to: J. Barburski, Cracow University of Economics, Department of Accountancy, Rakowicka street 27, 31-510 Cracow, Poland; e-mail: jacek_barburski@wp.pl
Given the above, cost cutting becomes the main, and sometimes even the only one, way of improving efficiency and one of the major criteria for the assessment of management efficiency.

The analysis and assessment of banks' activities are one of the main management tools facilitating a bank management's decision-making. In reality, indicatorbased methods have become the most common approach to performance assessment. In order to thoroughly recognise economic reality, in view of its 
complexity, it is ever more often necessary to seek out and make use of the methods and tools based on econometrics, statistics or operations research. The best solution would be to cross-feed between these methods, and further use the so-called integrated methods.

In the case of the concepts based on microeconomic production theory, the assessment of a studied object (a bank or a bank branch) depends on the efficiency with which the object transforms the factors of production (inputs) into effects, using technology at its disposal. Production technology identified as a set of output possibilities stands for a set of all possible combinations of inputs and outputs which can be realised by a given object. An efficient combination of inputs and outputs within a given technology may be determined by means of a frontier function.

The microeconomic theory deploys formalised mathematical models to analyse the three basic goal functions: the cost function, the revenue function and the profit function. The basic tools of the econometric analysis of a company's efficiency are constituted by stochastic frontier models of the cost, revenue and profit. Not only do they measure efficiency, but also allow assessing the degree to which companies implement certain goals. For example, if efficiency indicators produced by a cost function are relatively higher than analogous indicators furnished by a revenue or profit functions, then clearly the company cuts its costs in the best possible way.

Polish research into banks' cost efficiency was initiated by J. Osiewalski and J. Marzec as early as in 1996 and continued in the next years (1996-1997; 1998a; 1998b; 1998c; 1999).

Depending on the analysed stochastic frontier model, it is possible to distinguish the following categories of microeconomic efficiency related to the above goal functions: cost efficiency, revenue efficiency and profit efficiency. In the case of the revenue and profit functions, efficiency measurement is carried out on the basis of standard concepts (suitable for conditions of perfect competition) and alternative concepts (whenever the requirements of perfect competition are not satisfied).

The main aim of this paper is to present concepts involving the measurement of economic efficiency used to assess banks' activities under conditions of imperfect competition, at the same time constituting an important criterion of banks' assessment. It also presents the results of the measurement of the economic efficiency of the branches of the selected Polish commercial bank. The measurement was carried out on the basis of the alternative formulas of the revenue and profit functions, which relied on stochastic frontier models. On the other hand, the author used the Corrected Least Squares Method to estimate the efficiency models. In this empirical research, the following hypothesis was proposed: the economic efficiency indicators derived by using the alternative profit function should have values lower than the related indicators derived on the basis of the alternative revenue function.

\section{REASONS FOR THE EMERGENCE OF ALTERNATIVE EFFICIENCY MEASUREMENT}

Recently, an ever higher proportion of banks' revenue has been generated by way of non-traditional activities which bring in revenue from sources other than loan income. In many countries, the banking sector witnesses a decline in traditional banking as we know it and the growth of non-traditional activities. By merging financial services, banks avail themselves of additional benefits as well. As a result of the complementarity of services (cost economies of scope) there appears room to cut overall costs as running costs are spread across a broader product range, while the benefits of such complementarity (revenue economies of scope) come from a reduction in transaction costs associated with handling customers, transportation costs, the cost of research into the provision of services etc. To achieve revenue economies of scope, banks must be in a position to fix their own prices, and bank customers must exhibit their willingness to pay more for the combined financial services they are provided with. From a bank's customers' point of view, the price should not exceed the savings derived from the package of services provided by the bank. Sample savings for customers from the provision of financial service packages include transportation costs and time savings. 
When a bank's ability to set prices dovetails with customers' preference for a combination of services, this may bring about a link between the product range (structure) and the quantity of provided products and the generated revenue, which in turn may be estimated by way of the specification of the product quantity rather than prices in the revenue function. Banks' market power is an indispensable, however insufficient condition to ensure that their revenues reveal economies of scope. Indeed, banks can reap the benefits of their market potential by dictating prices, e.g. pricing individual products separately from their whole product offering without gaining any revenue economises of scope, arising from offering combined banking services (Berger, Humphrey \& Pulley, 1996, 1604).

Because banks provide an ever larger number of nontraditional services, the assessment of banks' efficiency by way of standard models has become somewhat less accurate, as these not infrequently fail to adequately capture economic reality, e.g. they do not factor in the results of non-traditional activities. The study results indicate that standard models tend to understate banks' efficiency (Rogers, 1998, 467), particularly in respect of banks pursuing non-traditional activities.

Banks are recognised to exercise control over the price level of some of their products. In the case of many loans, the need to collect detailed feedback on local economic conditions so as to be able to properly assess credit risk and determine additional security affords banks a certain degree of control over their loan interest rates. Banks also generate confidential information on their borrowers, which is costly for other lenders to elicit (Boyd \& Prescott, 1986) and the relationship between the borrower and his bank seems to solidify over time (Petersen \& Rajan, 1994; Berger \& Udell, 1995). The prices of such services as fees for taking deposits, a minimum compensating balance requirement whereby a portion of the loan is kept as security on a zero interest until the full repayment of the underlying loan, interest rates on consumer loans, current accounts (credit card debit), agricultural loans, loans for small enterprises and mediumsized corporate customers are all, to a certain extent, controlled by the bank (Berger, Humphrey \& Pulley, 1996, 1604).
In practice, by exercising their market power in respect of certain deposit and loan products, banks can differentiate prices between customer groups in different locations and over time. It is believed that some two-thirds of banks' revenue comes from services whose prices are determined by banks, and one-third from services where price acceptance is to be assumed (Humphrey \& Pulley, 1997, 79-80). As it seems, this argument justifies change in the specifications of the standard functions, in which prices are assumed to be exogenous data. Alternative efficiency assessment models, for simplicity's sake, assume that banks determine prices on all product markets, which is not true to fact, either. However, if a bank commanded the right information, it could develop a model factoring in a policy of price acceptance in just certain product markets. The use of models reflecting monopoly in the banking sector is also considered to be incorrect.

To recap, the standard revenue and profit functions would live up to the challenge of accurately measuring efficiency only in conditions of perfect completion. On the other hand, under conditions of imperfect competition, more accurate results are afforded by the formulas of the alternative revenue and profit functions. An alternative approach to assessing banks' efficiency should be deployed when at least one of the following conditions occurs (Berger \& Mester, 1997, 902):

- there appear basic unmeasured differences in the quality of banking services;

- output (production) is not entirely variable, hence banks cannot achieve all its levels and structures;

- product markets are not perfectly competitive, thus giving banks some leeway in fixing the level of some of their prices;

- product prices have not been measured correctly due to false numerical data.

\section{THE SHAPE OF THE ALTERNATIVE FRONTIER REVENUE FUNCTION}

In the alternative revenue function, in comparison with the standard formula, banks are assumed to have greater flexibility in respect of product prices 
than of production (output) levels; hence they treat the production volume as a principally exogenous factor at the time when they are making their decisions. If outputs are taken to be a datum, then also the quantity of inputs is determined by the production function or an appropriate transformation function. On the other hand, product prices may vary and so affect the revenue. This assumption allows testing revenue economies of scope, which constitutes its main asset.

As regards these assumptions, a maximum revenue growth occurs as a result of solving the following problem (Berger, Humphrey and Pulley, 1996, 1607):

$$
\max _{p} R=p^{\prime} y
$$

on condition that:

$g(y, p, w)=0$

where:

$y$ - output quantity vector,

$p$ - products price vector,

$w$ - vector of production factors prices,

$g$ - function of three variables: $y, p, w$ reflecting

external conditions and technology.

Having applied the Lagrange multipliers, we obtain the optimum product prices $\mathrm{p}(\mathrm{y}, \mathrm{w})$, which maximise the revenue. By definition, revenue is $R=p$ 'y, hence with the above condition, the revenue function will have the following formula:

$R=p^{\prime} y=p(y, w)^{\prime} y=R(y, w)$.

Assuming the two factors of production (the financial factor and labour) and one product (the volume of extended loans) and approximating the unknown alternative revenue function by expanding it into a Taylor series, we obtain a stochastic frontier model of the translog alternative revenue function (for crosssectional data) of the following formula:

$$
\begin{aligned}
\ln R_{i} & =\beta_{0}+\beta_{1} \ln w_{i, D}+\beta_{2} \ln w_{i, L}+\beta_{3} \ln y_{i}+ \\
& +\beta_{4} \ln w_{i, D} \ln w_{i, L}+\beta_{5} \ln w_{i, D} \ln y_{i}+ \\
& +\beta_{6} \ln w_{i, L} \ln y_{i}+\beta_{7}\left(\ln w_{i, D}\right)^{2}+\beta_{8}\left(\ln w_{i, L}\right)^{2}+ \\
& +\beta_{9}\left(\ln y_{i}\right)^{2}+v_{i}+z_{i}
\end{aligned}
$$

where:

$\ln R_{i}$ - ascertained (actual) revenue level of $i$ branch of the bank,

$\mathrm{w}_{\mathrm{i}, \mathrm{D}}$ - financial factor price (deposits and other acquired resources),

$\mathrm{w}_{\mathrm{i}, \mathrm{L}}$ - price of labour (level of average gross salary per employee),

$\mathrm{y}_{\mathrm{i}}$ - output volume (volume of loans and other receivables),

$v_{\mathrm{i}}-$ symmetric random components,

$\mathrm{z}_{\mathrm{i}}$ - components expressing the inefficiency of researched companies (technical or allocative) with independent distributions and solely negative values.

It is to be noted that an alternative revenue function contains the same set of exogenous variables as the cost function, the only difference being that revenue replaces costs as a dependent variable.

Having estimated the frontier revenue function, the revenue efficiency indicator (REi) for object $\mathrm{i}$ is calculated based on the formula:

$R E_{i}=\frac{\hat{R}^{i}}{\hat{R}^{\max }}$

where:

$\hat{R}^{i} \quad$ - actual realized revenue,

$\hat{R}^{\max }$ - maximum available revenue of the most efficient object in a sample.

The above indicator compares the actual revenue realised by object i (company) to a hypothetical maximum revenue which it could realise in the same period if it were as efficient as the best object in the researched sample.

\section{THE SHAPE OF THE ALTERNATIVE FRONTIER PROFIT FUNCTION}

The profit function has an alternative formula in very much the same manner as the revenue function, and the same may be used when the conditions underlying the standard function are not satisfied. 
When the conditions of perfect competition are satisfied, in order to assess efficiency, it is necessary that a standard formula of the profit function be assumed, which is (Rogers, 1998, 469):

$\pi=\pi\left(p, w, u_{c}, v_{\mathrm{c}}\right)$

where:

$\pi-$ the actual realised profit,

$p$ - a products price vector,

$w$ - a vector of production factor prices,

$u_{c}-$ a variable representing the inefficiency of a profit, and

$v_{\mathrm{c}}-$ a random element.

Yet, in most cases (the economies of individual countries), the assumptions of perfect competition are not satisfied. These cases are best served by an alternative formula of the profit function, which assumes that banks maximise a profit for the given output $\mathrm{y}$ and inputs prices $\mathrm{w}$, by selecting the prices of products $p$, simultaneously determining the size of variable inputs (at the given inputs, z) x. Considering the above assumptions, an alternative profit function is derived by solving the following problem (Humphrey \& Pulley, 1997, 81):

$$
\underset{p, x}{\max } \pi=P^{\prime} Q=(p, w) \cdot(y,-x)^{\prime}
$$

on condition that:

$g(p, y, w, z)=0$

$h(y, x)=0$

where: $g(p, y, w, z)$ stands for a set of possibilities for a bank to fix prices by way of transforming the size of $y, w$ and $z$ into prices of products $p$. This reflects the bank's assessment of its own competitive position and the assessment of customers' willingness to pay prices asked by the bank. Inputs prices $\mathrm{w}$ are included in function $g(8)$, as higher inputs prices may signal customers' willingness to accept higher prices. Markets where inputs prices are higher (e.g. cities having a higher cost of living, e.g. an office rent) are where customers are inclined to pay higher prices for banking products. Banks commanding flawed information on demand could use inputs prices $\mathrm{w}$ to assess demand.

The use of the Lagrange multipliers allows finding the best level of product prices, as function $p=p(y$, $\mathrm{w}, \mathrm{z})$ and the optimum size of inputs $\mathrm{x}=\mathrm{x}(\mathrm{y}, \mathrm{z})$. After solving this problem and substituting the acquired optimum size to the profit formula, the following alternative profit function is obtained:

$$
\begin{aligned}
\pi & =P^{\prime} Q=[p(y, w, z), w][y,-x(y, z)]^{\prime}= \\
& =\pi(y, w, z)
\end{aligned}
$$

The main benefit afforded by the alternative profit function is that it captures more appropriate specifications when the forces of the market come to play. Moreover, the prices of products $\mathrm{p}$, which appear in the standard profit function, are measured less accurately than in the alternative approach as certain significant elements of lenders' and borrowers' prices are not accounted for in the available information.

While considering what appropriate function to select to best measure efficiency, it is advisable to pay attention to a number of important issues. An alternative profit function makes it possible to control unmeasured differences in product quality, which a standard profit function does not, because it factors in additional revenue originating in the sale of betterquality products. It should also be noted that an alternative profit function basically resembles the cost function, except that a profit is additionally accounted for by a dependent variable.

Banks often differ on account of the size of their business. Hence, it is obvious that small banks are not in a position to attain the size of operations (e.g. the size of output or a profit) typical of large banks. Thus, if a standard profit function is used, large banks may reveal higher profit efficiency due to the fact that small banks cannot attain the former's output level. On the other hand, an alternative profit function compares banks' ability to generate profit for the same output level, and so reduces the degree of deviation which may occur in the standard measurement of a profit (Berger \& Mester, 1997, 903).

The standard profit function assumes that product prices are as given, hence a bank may sell as many 
products as it simply wishes, without a need to depress prices. This may result in understating standard profit efficiency in banks with output falling below the efficiency scale as they have to reduce prices to increase output and thus cannot gain a maximum potential profit. In situations where banks have a certain market position, it is fair to consider output to be a value relatively stable over a short time period, and allow a possibility of fixing prices. The given bank endeavouring to generate an optimum profit will fix its prices at a level the market will accept its output and service quality. An alternative profit function also factors in the difference between the possibility of using individual banks' market power (Berger and Mester, 1997, 903-904).

By using an intermediation approach recommended by Sealey and Lindlay (1977), and assuming the two variable production factors (the value of deposits taken and the value of salaries), one fixed netput (physical capital measured in terms of surface in square metres) and one product (the value of loans granted), the stochastic frontier model of the translog alternative revenue function may be written as follows:

$$
\begin{aligned}
\ln \pi_{\mathrm{i}} & =\alpha_{0}+\alpha_{1} \ln \mathrm{w}_{\mathrm{i}, \mathrm{D}}+\alpha_{2} \ln \mathrm{w}_{\mathrm{i}, \mathrm{L}}+\alpha_{3} \ln \mathrm{y}_{\mathrm{i}}+ \\
& +\alpha_{4} \ln \mathrm{K}_{\mathrm{i}}+\alpha_{5} \ln \mathrm{w}_{\mathrm{i}, \mathrm{D}} \ln \mathrm{w}_{\mathrm{i}, \mathrm{L}}+\alpha_{6} \ln \mathrm{w}_{\mathrm{i}, \mathrm{D}} \ln \mathrm{y}_{\mathrm{i}}+ \\
& +\alpha_{7} \ln \mathrm{w}_{\mathrm{i}, \mathrm{D}} \ln \mathrm{K}_{\mathrm{i}}+\alpha_{8} \ln \mathrm{w}_{\mathrm{i}, \mathrm{L}} \ln \mathrm{y}_{\mathrm{i}}+ \\
& +\alpha_{9} \ln \mathrm{w}_{\mathrm{i}, \mathrm{L}} \ln \mathrm{K}_{\mathrm{i}}+\alpha_{10} \ln \mathrm{y}_{\mathrm{i}}, \ln \mathrm{K}_{\mathrm{i}}+ \\
& +\alpha_{11}\left(\ln \mathrm{w}_{\mathrm{i}, \mathrm{D}}\right)^{2}+\alpha_{12}\left(\ln \mathrm{w}_{\mathrm{i}, \mathrm{L}}\right)^{2} \\
& +\alpha 13\left(\ln \mathrm{y}_{\mathrm{i}}\right)^{2}+\alpha_{14}\left(\ln \mathrm{K}_{\mathrm{i}}\right)^{2}+v_{\mathrm{it}}+\mathrm{z}_{\mathrm{it}}
\end{aligned}
$$

where:

$\ln \pi_{i}$ - ascertained profit level of $i$ branch of the bank,

$\mathrm{w}_{\mathrm{i}, \mathrm{D}}$ - price of financial factor (deposits and other acquired resources),

$\mathrm{w}_{\mathrm{i}, \mathrm{L}}$ - price of labour (level of average gross salary per employee),

$\mathrm{y}_{\mathrm{i}}$ - size of output (loans and other offered resources),

$\mathrm{K}_{\mathrm{i}}$ - fixed netputs (physical capital) engaged, measured in terms of surface in the square metres of the proprietary and rented office space,

$\mathrm{z}_{\mathrm{i}}$ - components expressing the inefficiency of the researched companies (technical or allocative) with independent distributions and solely negative values.
Having assessed the above frontier profit function, one can compute the profit efficiency indicator as follows:

$\pi E_{i}=\frac{\hat{\pi}^{i}}{\hat{\pi}^{\max }}$

where:

$\hat{\pi}^{i} \quad$ - actual realized profit,

$\hat{\pi}^{\max }$ - maximum value of profit that can be realised by the most efficient object in the sample.

The above indicator reveals the relation between a profit actually realised by object $i$ (the company) and a hypothetical maximum profit, which it could generate over the same time period if it were as efficient as the best object in the researched sample.

\section{ECONOMETRIC MEASUREMENT OF THE BANK BRANCHES' EFFICIENCY CARRIED OUT BY MEANS OF AN ALTERNATIVE FRONTIER FUNCTION OF REVENUE AND PROFITS}

The main problem underlying the econometric analysis of efficiency involves estimating the parameters of the given frontier function and the indicators of efficiency (inefficiency) levels. In order to model frontier functions, one can use classic econometric methods as well as linear and square programming methods. The latter are prone to a number of serious flaws, the most important being their high sensitivity to atypical observations and a failure to accommodate information on the distribution of the inefficiency variable.

The simplest single-equation estimation models for stochastic frontier models are those based on the Least Squares Method (LSM). In the case of the cross-section of data, when the frontier function (of revenue of profit) is linear relative to $\mathrm{K}+1$ parameters, it assumes the following shape:

$y_{i}=\alpha 0+x_{i} \beta(-0)+v_{i}+u_{i}, \quad$ dla $i=1, \ldots, N$

where: 
$\beta_{(-0)}=\left[\beta_{1}, \ldots, \beta \mathrm{K}\right]^{\mathrm{T}}$ is a vector of a the $\mathrm{K}$ number of unknown technology parameters (barring free time $\alpha 0$ ),

$v_{i}$ - random components with identical independent normal distributions with a zero mean and finite variance,

$u_{i}-$ components modeling potential ineffectiveness ( $v i$ and ui are random variables independent of each other).

The easier way to determine a frontier function is called the Corrected Ordinary Least Squares (COLS) and was proposed by Winsten (1957), although it is attributed to Gabrielsen (1975). It consists in using the Least Squares Method to estimate the right equation and determining the rests $\hat{\varepsilon}_{\mu, i}=y_{i}-\hat{y}_{i}$. It is also assumed that one of the companies under research is fully efficient and the inefficiency of the others is benchmarked against it.

Koop and Mullahy (1990) also proposed deploying the Generalized Method of Moments to estimate stochastic frontier models. Additionally, use can also be made of the Maximum Likelihood Method estimation (MLM).

An empirical efficiency analysis was carried out for branches of a Polish commercial bank. The quarterly $\left(\mathrm{Q}_{1}, \mathrm{Q}_{2}\right.$ and $\mathrm{Q}_{3}$ - one quarter was ignored as pertinent data was not available) results used in the study for an alternative revenue function come from the bank's 58 branches $(\mathrm{T}=3, \mathrm{~N}=58)$ while for the alternative profit function they are derived from 54 branches $(4$ branches were overlooked as they reported negative performance).

The branches are dispersed among towns and sites of different sizes and regions of a mixed economic profile (industrial, tourist, agricultural). The range of services provided depends on the nature of the local market and resultant customer needs. Each branch has a unique number assigned to it as its ID number.

For the purposes of the econometric analysis of the branches' economic efficiency, use was made of the stochastic frontier models of the alternative revenue and profit functions for the cross-sectional data. On the other hand, in order to estimate the parameters of the above models, use was made of the Corrected
Least Squares Method (SLSM), mostly on account of the simplicity of calculations. The results of the calculations are presented in Table 1 and Table 2. Apart from the efficiency indicators of each branch, the Tables also present a branch's place in the ranking.

It should be noted that the fit between empirical data and theoretical values (measured by means of the determination coefficient $\mathrm{R}_{2}$ ) is very high for the alternative revenue function. However, because of the simplified assessment method and measurement of efficiency itself which was used (which, among other things, assumes a lack of pure random deviations) the estimated individual inefficiency levels should be considered as rather inaccurate. This is further corroborated by the fact that the efficiency measures obtained reveal considerable variations. Similar reservations hold for the alternative revenue function, for which the fit is markedly smaller. In order to obtain more accurate efficiency measures, more sophisticated assessment methods, e.g. those based on the Bayesian perspective, are recommended.

Regardless of the above comments, it should be emphasised that the branch rankings based on computed efficiency indicators should in both cases be taken with conviction as reliable and easily lending themselves to further comparative analyses.

Based on the efficiency indicators produced by the alternative revenue function, it can be stated that the branches of the studied bank could have generated revenues higher by an average of $20.8 \%$ in $\mathrm{Q}_{1}$ to $26.5 \%$ in $Q_{3}$, if they had sold more of the products or paid lower prices for their factors of production (Table 1).

The synthetic assessment of the economic efficiency of the branches under analysis is best revealed by the results produced by the alternative profit function (used under conditions of imperfect competition). As a matter of fact, the function contains both cost and revenue effects.

The average efficiency level of the analysed branches ranged between 0.520 (52.0\% of the potential) in $\mathrm{Q}_{1}, 0.306$ (30.6\%) in $\mathrm{Q}_{2}$ and 0.377 (37.7\%) in $\mathrm{Q}_{3}$. The following branches reveal the best efficiency (Table 2): 
Table 1 Revenue efficiency indicators for bank branches computed on the basis of the alternative revenue function

\begin{tabular}{|c|c|c|c|c|c|c|}
\hline Number of branch & I Quarter & Ranking & II Quarter & Ranking & III Quarter & Ranking \\
\hline 1 & 0,714 & 49 & 0,610 & 55 & 0,653 & 46 \\
\hline 2 & 0,738 & 40 & 0,681 & 50 & 0,613 & 51 \\
\hline 3 & 0,737 & 41 & 0,810 & 25 & 0,812 & 16 \\
\hline 4 & 0,852 & 15 & 0,881 & 12 & 0,769 & 22 \\
\hline 5 & 0,758 & 35 & 0,764 & 37 & 0,666 & 43 \\
\hline 6 & 0,683 & 54 & 0,769 & 36 & 0,664 & 44 \\
\hline 7 & 0,894 & 9 & 0,852 & 18 & 0,755 & 25 \\
\hline 8 & 0,808 & 27 & 0,819 & 23 & 0,707 & 37 \\
\hline 9 & 0,887 & 12 & 0,914 & 6 & 0,698 & 39 \\
\hline 10 & 0,927 & 5 & 0,966 & 3 & 0,812 & 15 \\
\hline 11 & 0,745 & 39 & 0,714 & 44 & 0,708 & 36 \\
\hline 12 & 0,678 & 55 & 0,707 & 46 & 0,718 & 34 \\
\hline 13 & 0,938 & 4 & 0,927 & 5 & 1,000 & 1 \\
\hline 14 & 0,836 & 20 & 0,827 & 21 & 0,797 & 17 \\
\hline 15 & 0,867 & 13 & 0,890 & 10 & 0,825 & 12 \\
\hline 16 & 0,791 & 31 & 0,782 & 31 & 0,775 & 21 \\
\hline 17 & 0,623 & 57 & 0,605 & 57 & 0,551 & 56 \\
\hline 18 & 1,000 & 1 & 1,000 & 1 & 0,833 & 10 \\
\hline 19 & 0,721 & 45 & 0,806 & 26 & 0,766 & 23 \\
\hline 20 & 0,716 & 19 & 0,746 & 13 & 0,754 & 50 \\
\hline 21 & 0,812 & 25 & 0,774 & 34 & 0,727 & 31 \\
\hline 22 & 0,826 & 22 & 0,850 & 19 & 0,782 & 19 \\
\hline 23 & 0,761 & 34 & 0,773 & 35 & 0,676 & 41 \\
\hline 24 & 0,847 & 16 & 0,864 & 16 & 0,932 & 3 \\
\hline 25 & 0,798 & 30 & 0,814 & 24 & 0,730 & 29 \\
\hline 26 & 0,828 & 21 & 0,780 & 32 & 0,826 & 11 \\
\hline 27 & 0,769 & 33 & 0,700 & 48 & 0,659 & 45 \\
\hline 28 & 0,777 & 32 & 0,788 & 28 & 0,856 & 5 \\
\hline 29 & 0,899 & 8 & 0,860 & 17 & 0,850 & 8 \\
\hline 30 & 0,843 & 18 & 0,779 & 33 & 0,728 & 30 \\
\hline 31 & 0,798 & 29 & 0,707 & 45 & 0,629 & 49 \\
\hline 32 & 0,837 & 48 & 0,877 & 41 & 0,629 & 26 \\
\hline 33 & 0,863 & 14 & 0,912 & 8 & 0,861 & 4 \\
\hline 34 & 0,707 & 52 & 0,622 & 53 & 0,574 & 55 \\
\hline 35 & 0,734 & 42 & 0,693 & 49 & 0,715 & 35 \\
\hline 36 & 0,746 & 38 & 0,736 & 43 & 0,723 & 33 \\
\hline 37 & 0,719 & 46 & 0,705 & 47 & 0,703 & 38 \\
\hline 38 & 0,375 & 58 & 0,430 & 58 & 0,447 & 58 \\
\hline
\end{tabular}




\begin{tabular}{ccccccc}
\hline Number of branch & I Quarter & Ranking & II Quarter & Ranking & III Quarter & Ranking \\
39 & 0,911 & 6 & 0,872 & 15 & 0,848 & 9 \\
40 & 0,719 & 47 & 0,759 & 38 & 0,677 & 40 \\
41 & 0,677 & 56 & 0,678 & 51 & 0,640 & 48 \\
42 & 0,812 & 26 & 0,787 & 29 & 0,785 & 18 \\
43 & 0,845 & 17 & 0,872 & 14 & 0,852 & 7 \\
44 & 0,940 & 3 & 0,883 & 11 & 0,781 & 20 \\
45 & 0,713 & 50 & 0,667 & 52 & 0,605 & 53 \\
46 & 0,894 & 10 & 0,841 & 20 & 0,760 & 24 \\
47 & 0,701 & 53 & 0,614 & 54 & 0,610 & 52 \\
48 & 0,730 & 43 & 0,749 & 40 & 0,675 & 42 \\
49 & 0,955 & 2 & 0,947 & 4 & 0,818 & 14 \\
50 & 0,892 & 11 & 0,789 & 27 & 0,645 & 47 \\
51 & 0,818 & 24 & 0,991 & 2 & 0,853 & 6 \\
52 & 0,825 & 23 & 0,897 & 9 & 0,957 & 2 \\
53 & 0,755 & 36 & 0,786 & 30 & 0,737 & 28 \\
54 & 0,724 & 44 & 0,738 & 42 & 0,726 & 32 \\
55 & 0,755 & 37 & 0,757 & 39 & 0,605 & 54 \\
56 & 0,806 & 28 & 0,827 & 22 & 0,749 & 27 \\
57 & 0,709 & 51 & 0,609 & 56 & 0,539 & 57 \\
58 & 0,907 & 7 & 0,913 & 7 & 0,819 & 13 \\
\hline Minimum value & 0,375 & & 0,430 & & 0,447 & \\
Average value & 0,792 & & 0,788 & & 0,735 & \\
Determination & 0,962 & & 0,957 & & 0,958 & \\
Coefficient $\mathrm{R}^{2}$ & & & & & \\
\hline
\end{tabular}

Source: Author's own calculations

- Q1: branch no.: 46, 36, 16, 31, 12;

- Q2: branch no.: 16, 8, 9, 14, 48;

- Q3: branch no.: 22, 48, 26, 40, 12.

The least effective are the following branches:

- Q1: branch no.: 5, 39, 11, 17, 49;

- Q2: branch no.: $11,35,38,5,32$;

- Q3: branch no.: 5, 12, 30, 52, 29.
It should be added that, depending on the assessment criterion used (alternative revenue or profit function) and the studied period, the branch rankings differed (Table 1 and Table 2). 
Table 2 Profit efficiency indicators for bank branches computed on the basis of the alternative profit function

\begin{tabular}{|c|c|c|c|c|c|c|}
\hline Number of branch & I Quarter & Ranking & II Quarter & Ranking & III Quarter & Ranking \\
\hline 1 & 0,465 & 32 & 0,161 & 46 & 0,278 & 33 \\
\hline 2 & 0,436 & 35 & 0,247 & 32 & 0,245 & 41 \\
\hline 3 & 0,633 & 13 & 0,334 & 17 & 0,616 & 7 \\
\hline 4 & 0,362 & 46 & 0,215 & 37 & 0,282 & 32 \\
\hline 5 & 0,133 & 54 & 0,141 & 51 & 0,025 & 54 \\
\hline 6 & 0,671 & 12 & 0,296 & 23 & 0,368 & 23 \\
\hline 7 & 0,477 & 31 & 0,251 & 31 & 0,248 & 39 \\
\hline 8 & 0,529 & 24 & 0,849 & 2 & 0,229 & 45 \\
\hline 9 & 0,752 & 8 & 0,845 & 3 & 0,337 & 25 \\
\hline 10 & 0,478 & 30 & 0,190 & 40 & 0,310 & 27 \\
\hline 11 & 0,256 & 52 & 0,015 & 54 & 0,092 & 53 \\
\hline 12 & 0,771 & 5 & 0,376 & 9 & 0,625 & 5 \\
\hline 13 & 0,511 & 25 & 0,300 & 22 & 0,328 & 26 \\
\hline 14 & 0,690 & 10 & 0,791 & 4 & 0,378 & 22 \\
\hline 15 & 0,499 & 27 & 0,254 & 30 & 0,454 & 13 \\
\hline 16 & 0,852 & 3 & 1,000 & 1 & 0,565 & 11 \\
\hline 17 & 0,268 & 51 & 0,219 & 35 & 0,308 & 28 \\
\hline 18 & 0,418 & 37 & 0,207 & 38 & 0,300 & 30 \\
\hline 19 & 0,400 & 40 & 0,318 & 21 & 0,407 & 18 \\
\hline 20 & 0,601 & 17 & 0,395 & 7 & 0,384 & 21 \\
\hline 21 & 0,332 & 48 & 0,219 & 36 & 0,229 & 44 \\
\hline 22 & 0,715 & 9 & 0,388 & 8 & 1,000 & 1 \\
\hline 23 & 0,609 & 16 & 0,355 & 15 & 0,577 & 9 \\
\hline 24 & 0,579 & 19 & 0,275 & 27 & 0,449 & 15 \\
\hline 25 & 0,379 & 44 & 0,181 & 42 & 0,238 & 43 \\
\hline 26 & 0,547 & 22 & 0,338 & 16 & 0,952 & 3 \\
\hline 27 & 0,673 & 11 & 0,280 & 25 & 0,520 & 12 \\
\hline 28 & 0,534 & 23 & 0,296 & 24 & 0,451 & 14 \\
\hline 29 & 0,509 & 26 & 0,145 & 48 & 0,186 & 50 \\
\hline 30 & 0,409 & 39 & 0,361 & 14 & 0,137 & 52 \\
\hline 31 & 0,811 & 4 & 0,462 & 6 & 0,600 & 8 \\
\hline 32 & 0,381 & 43 & 0,142 & 50 & 0,192 & 49 \\
\hline 33 & 0,396 & 41 & 0,276 & 26 & 0,261 & 37 \\
\hline 34 & 0,552 & 20 & 0,257 & 29 & 0,354 & 24 \\
\hline 35 & 0,333 & 47 & 0,137 & 53 & 0,240 & 42 \\
\hline 36 & 0,930 & 2 & 0,319 & 20 & 0,622 & 6 \\
\hline 37 & 0,310 & 49 & 0,174 & 44 & 0,267 & 36 \\
\hline 38 & 0,384 & 42 & 0,139 & 52 & 0,216 & 47 \\
\hline
\end{tabular}




\begin{tabular}{|c|c|c|c|c|c|c|}
\hline Number of branch & I Quarter & Ranking & II Quarter & Ranking & III Quarter & Ranking \\
\hline 39 & 0,253 & 53 & 0,157 & 47 & 0,276 & 34 \\
\hline 40 & 0,614 & 14 & 0,334 & 18 & 0,659 & 4 \\
\hline 41 & 0,770 & 7 & 0,329 & 19 & 0,409 & 17 \\
\hline 42 & 0,363 & 45 & 0,168 & 45 & 0,226 & 46 \\
\hline 43 & 0,770 & 6 & 0,371 & 11 & 0,397 & 20 \\
\hline 44 & 0,409 & 38 & 0,223 & 34 & 0,260 & 38 \\
\hline 45 & 0,420 & 36 & 0,232 & 33 & 0,306 & 29 \\
\hline 46 & 1,000 & 1 & 0,364 & 12 & 0,572 & 10 \\
\hline 47 & 0,613 & 15 & 0,375 & 10 & 0,216 & 48 \\
\hline 48 & 0,580 & 18 & 0,487 & 5 & 0,963 & 2 \\
\hline 49 & 0,270 & 50 & 0,191 & 39 & 0,285 & 31 \\
\hline 50 & 0,484 & 29 & 0,180 & 43 & 0,402 & 19 \\
\hline 51 & 0,459 & 33 & 0,143 & 49 & 0,247 & 40 \\
\hline 52 & 0,442 & 34 & 0,185 & 41 & 0,151 & 51 \\
\hline 53 & 0,487 & 28 & 0,361 & 13 & 0,276 & 35 \\
\hline 54 & 0,552 & 21 & 0,271 & 28 & 0,448 & 16 \\
\hline Minimum value & 0,133 & & 0,015 & & 0,025 & \\
\hline Average value & 0,520 & & 0,306 & & 0,377 & \\
\hline $\begin{array}{l}\text { Determination } \\
\text { coefficient } \mathrm{R}^{2}\end{array}$ & 0,768 & & 0,654 & & 0,660 & \\
\hline
\end{tabular}

Source: Author's own calculations

\section{CONCLUSION}

The above concepts of the revenue and profit efficiency measurement may well be used under the conditions of imperfect competition amongst banks. The use of an alternative revenue function allows studying revenue maximisation in the given bank (branch). The alternative profit function, which facilitates the assessment of effects, not merely on the revenue front but also on the cost side, offers a more synthetic measurement of economic efficiency. In both cases, the computation of the efficiency level is based upon revenue or profit optimisation (maximisation) and is carried out by means of a stochastic frontier model of the profit function having strong microeconomic and statistical foundations.

Thanks to the research, the research hypothesis was confirmed. Based on the research it was revealed that the economic efficiency indicators produced by the alternative profit function are significantly lower than the corresponding rates yielded by the alternative revenue function in view of the fact that the profit function contains the cost effects.

One defect of the studies, as already mentioned, attributable to the use of a simplified estimation method, is that the individual efficiency levels of the tested objects are too low. The characteristics of the production process and the efficiency of individual companies can comprehensively be arrived at only on the basis of the Bayesian perspective, combining, in the estimation process, both the pre-knowledge of the analyzed phenomenon (e.g. resulting from economic theory) and the information contained in the sample, which is proponed and presented by Koop, Osiewalski and Steel (1994). Thus, the use of more advanced estimation methods capable of producing more accurate measurement results is an open issue available for further research. 
In order to complete the assessment of the economic efficiency of the researched objects, it would also be advisable to measure the economic efficiency of costs and use panel data as well. Undoubtedly, it would also be very interesting to carry out similar studies for other banks and compare economic efficiency between banks.

The main benefit conferred by the study is in the shape of the branch ranking developed on the basis of the computed efficiency indicators. The assessment method used does not have a meaningful impact on the preparation of the ranking of the efficiency measures and, subsequently, the ranking of the individual branches. It can be assumed with reasonable confidence that the branch rankings are reliable, which in turn permits the comparative analyses of the branches.

\section{REFERENCES}

Berger, A. N. (1993). Distribution - Free Estimates of Efficiency in the U. S. Banking Industry and Tests of the Standard Distributional Assumptions. Journal of Productivity Analysis, 4, 261-292.

Berger, A. N., \& Humphrey, D. (1991). The Dominance of Inefficiencies Over Scale and Product Mix Economies in Banking. Journal of Monetary Economics, 28, 117-148.

Berger, A. N., Humphrey, D. B., \& Pulley, L. M. (1996). Do Consumers Pay for One - top Banking? Evidence from an Alternative Revenue Function. Journal of Banking and Finance, 20, 1601-1621

Berger, A. N., \& Mester, L. J. (1997). Inside the Black Box: What Explains Differences in the Effeciencies of Financial Institutions? Journal of Banking and Finance, 21, 895-947.

Berger, A. N., \& Udell, G. (1995). Relationships: Lending and Lines of Credit in Small Firm Finance. Journal of Business, 68, 351-381.

Boyd, J., \& Prescott, E. (1986). Financial Intermediary Coalitions. Journal of Economic Theory, 38, 211-232.

Ferrier, G. D., \& Lovell, C. A. K. (1990). Measuring Cost Efficiency in Banking: Econometric and Linear Programming Evidence. Journal of Econometrics, 46, 229-245.

Gabrielsen, A. (1975). On Estimating Efficient Productions. Working Paper A-35, Bergen, Norway: Chr. Michelsen Institute, Department of Humanitities and Social Sciences.
Humphrey, D. B., \& Pulley, L. B. (1997). Banks' Responses to Deregulation: Profits, Technology and Efficiency. Journal of Money, Credit and Banking, 29, 73-93.

Koop, G., Osiewalski, J., \& Steel, M. F. J. (1994). Bayesian Efficiency Analysis with a Flexible Form: The AIM Cost Function. Journal of Business and Economic Statistics, 12, 339346.

Kopp, R. J., \& Mullahy, J. (1990). Moment - Based Estimation and Testing of Stochastic Frontier Models. Journal of Econometrics, 46, 165-183.

Marzec, J. (1998). Produkty i czynniki produkcji w badaniach efektywności kosztowej banków. Prace Naukowe AE we Wrocławiu, 761, 156-164.

Marzec, J. (1999). Produkty, czynniki produkcji i funkcja kosztów w badaniach efektywności kosztowej banków. Ekonomista, 3, 281-304.

Marzec, J., \& Osiewalski, J. (1996-1997). Pomiar efektywności kosztowej banków: zarys metodologii. Folia Oeconomica Cracoviensia, 39-40, 65-81.

Osiewalski, J., \& Marzec, J. (1998a). Bayesian analysis of cost efficiency with an application to bank branches. In E. Miklaszewska (Ed.), Global Tendencies and Changes in East European Banking (pp. 151-166). Kraków, Poland: Jagiellonian University.

Osiewalski, J., \& Marzec, J. (1998b). Analiza bayesowska efektywności kosztowej oddziałów banku: założenia i wyniki. In Prognozowanie $\mathrm{w}$ zarządzaniu firmą. Prace Naukowe AE we Wrocławiu, 808, 24-33.

Osiewalski, J., \& Marzec, J. (1998c). Nowoczesne metody Monte Carlo w bayesowskiej analizie efektywności kosztowej banków. In Zastosowania rozwiązań informatycznych w bankowości, Prace Naukowe AE we Wrocławiu, 797, 182-195.

Petersen, M., \& Rajan, R. (1994). Benefits of Firm - Creditor Relationships: Evidence from Small Business Date. Journal of Finance, 49, 3-37.

Rogers, K. E. (1998). Nontraditional Activities and the Efficiency of US Commercial Banks. Journal of Banking and Finance, 22, 467-482.

Sealey, C. W., \& Lindley, J. T. (1977). Inputs, Outputs and Theory of Production and Cost at Depository Financial Institutions. Journal of Finance, 32, 1251-1266.

Winsten, C. B. (1957). Discussion on Mr. Farrell's Paper. Journal of the Royal Statistical Society, Series A, General, 120, Part 3, 282-284. 


\author{
Received on $30^{\text {th }}$ January 2013, \\ after revision, \\ accepted for publication on $19^{\text {th }}$ April 2013
}

Jacek Barburski is a lecturer at the Department of Accounting, Faculty of Management, Cracow University of Economics, Cracow, Poland. He received his a Ph.D. degree in Economic Sciences, for his work entitled "Comparison of Traditional and Econometric Assessment Methods of the Economic Efficiency of Banks and Their Branches".

\title{
MERENJE EKONOMSKE EFIKASNOSTI BANAKA U USLOVIMA NESAVRŠENE KONKURENCIJE
}

\author{
Jacek Barburski \\ Fakultet za menadžment, Ekonomski univerzitet u Krakovu, Krakov, Poljska
}

Jedan od načina merenja ekonomske efikasnosti banaka i njihovih filijala predstavlja ekonometrijski pristup zasnovan na graničnim stohastičkim funkcijama. U ovom pristupu mogu se razmatrati tri osnovne ciljne funkcije: funkcija troškova, funkcija prihoda i funkcija dobiti. Cilj ovog rada je da predstavi alternativne (u odnosu na standardnu formulu) koncepte merenja efikasnosti prihoda i dobiti, koji predstavljaju važan kriterijum za procenu poslovanja banaka. Takođe, u radu su prezentirani rezultati empirijskih proučavanja efikasnosti prihoda i dobiti, na primeru odabrane komercijalne banke. U teorijskom delu rada, polazi se od premisa procene alternativne efikasnosti, nakon čega slede formule graničnih funkcija prihoda i dobiti. Reč je o formulama koje isključivo mogu biti upotrebljene u uslovima nesavršene konkurencije između banaka. U empirijskom delu rada, fokus je na primeni dotičnih modela za procenu efikasnosti filijala izabrane poljske banke. Na osnovu proračuna, dobijeni su pokazatelji efikasnosti prihoda i dobiti i rangirane filijale koje su bile predmet izučavanja u tri različita kvartala. Zbog korišćenja jednostavnog metoda za procenu (Korigovani metod najmanjih kvadrata), dobijeni i prikazani pokazatelji efikasnosti nisu dovoljno precizni da bi se mogli koristiti u daljem istraživanju. S druge strane, rangiranja na osnovu upotrebljenog metoda su pouzdana i mogu se koristiti za dalje procene i poređenja.

Ključne reči: merenje efikasnosti banaka, ekonomska efikasnost, efikasnost alternativnog prihoda, efikasnost alternativne dobiti, granični stohastički modeli

JEL Classification: C01, C61, D24, G21 